\title{
短文理解における動作イメージの検討
}

$\bigcirc$ 伊藤 尚枝

(惠泉女学園大学)

キーワード : 短文理解, 動作主, 動作シミュレーション

The inquest of action image in short sentence comprehension

Hisae Ito

(Ke isen University)

Key Words : Short sentence comprehension, Agent, Action simulation

目的

de Vega et al.(2004)は, 例えば「木を切り倒す」「フェ ンスにペンキを塗る」のように，同時に実行できない動作を 含む2文を, 副詞(while, またはafter) でつないで重文を作 り，参加者に呈示した。重文の意味が通るかどうかを尋ねる と, ”after”の場合は意味が通るが, ”while”の場合は通らな いと答えた。さらに，読解時間を比較すると，”after”のほう が”while”よりも有意に短かった。この結果から，同時には実 行できない動作文を”after”でつなぐと，動作を逐次的にシ ミュレーションして、辻褛の合う状況として表象できるよう になると主張している.

Gl enberg \& Kaschak(2002)によれば，短文で記述した行動 （例：あなたがマークにペンを与えた）と，参加者が要請され た行動（例：身体に向かう行動に対して反応する）の方向が 一致しないと, 応答時間が増加すると報告している。つま り, 動作のシミュレーションは, 読者自身の具体的な身体運 動として表象されている可能性が高い.

本研究では, ”after”の代わりに「そのあと」を使用する. そして，2文の動作主を操作して，同一人物の場合と（一致条 件），異なる人物の場合（不一致条件）とを設定する。指標 として，単語の再生課題を用いる．2条件の再生成績に差があ らわれたときは、身体運動を媒介にしてシミュレーションを するときに、動作主の次元が影響を与えると推測できる。

\section{方 法}

実験参加者 大学生28名（18～20歳）を，一致条件（14名） と, 不一致条件（14名）とにランダムに割りあてた.

呈示文 どちらの条件にも，2文を1組として，18組を呈示し た. Table 1に各条件の呈示文を，2組ずつ抜粋して示す。 致条件では，「（名詞）を〜する」の2文を組み合わせた。他 方, 不一致条件では，「（名詞）を〜する」と「（名詞）を 〜してもらう」の2文を組み合わせた。2文の間には，「その あと」という語が必ず入っていた.

実験計画 1 要因の参加者間計画. 要因は, 呈示する2文の動 作主の [一致/不一致］であった。一致条件では，2文の動詞 の動作主が同じである．他方，不一致条件では，文末の表現 （〜する，〜してもらう）に応じて，動作主が異なると読み取 れる.

手続き 参加者に, 条件に応じた呈示文をパワーポイントで 呈示した。スライド1枚につき2文を1ペアにして呈示して，7 秒間黙読してもらつた。参加者の課題は, 呈示された2つの文 中に含まれる単語（名詞）を覚えることであった。単語は, 1 文につき1つずつ指定したが，一緒に呈示した2文の単語をぺ アにして覚えてもらった．記憶する単語は，下線を引いて示 した（Table 1内の二重線と太線部分）。スライドをすべて （18枚）呈示した後, 簡単な計算をしてもらってから, 再生テ ストを受けてもらった，再生テストでは，第1文の単語

(Table 1内の二重線）を手がかりにして，ペアである第2文
の単語（Table 1内の太線）を書いてもらった.

\section{結 果}

ペアの相方の単語を正しく再生できたときに，1点を与えて得 点化した（18点満点）。一致条件の平均值は 3.27 点 $(S D=$ 1.90) で，不一致条件の平均值は，2.14点（ $S D=1.51 ）$ だった（Figure 1)．2条件の平均值に差があるかどうかを調 ベるために，対応のないt検定を実行したところ，5\%水準で 有意な差が認められた $(t(26)=1.76, p<.05)$.

\section{考 察}

一致条件のほうが再生成績が高かった。動作主が一致して いる方が，自身の身体運動を媒介にして，動作のシミュレー ションしやすかったと推測できる.

\section{引用文献}

de Vega, M., Robertson, D. A., Gl enberg, A. M., Kaschak, M. P.,\& Rinck, M. (2004) . 0n do ing two things at once: Temporal constraints on actions in language comprehension. Memory \& Cognition, 32, 10331043.

Gl enberg. A.M. , \& Kaschak,M.P. (2002). Grounding language in action. Psychonomic Bulletin \& Review, 9, $558-565$.

Table1 各条件で使用した呈示文(抜粋)

(動作主)一致条件

(1) ジャケットを脱ぐ。そのあと、引き出しを開ける。

(2) 薬を開ける。そのあと、ゴミを捨てる。

(動作主)不一致条件

(1) 洋ャケットを脱ぐ。そのあと、引き出しを開けてもらう。

(2) 薬を開ける。そのあと、ゴミを捨ててもらう。

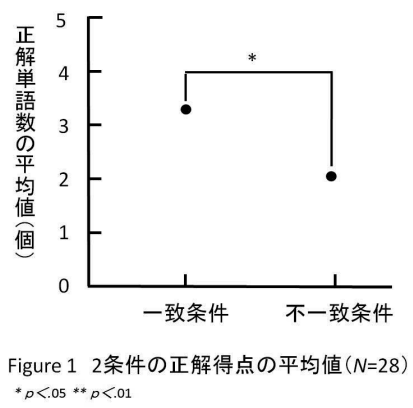

